\title{
Characterization of Yersinia enterocolitica, $Y$. intermedia, $Y$. aldovae, $Y$. frederiksenii, Y. kristensenii and $Y$. pseudotuberculosis by Electrophoretic Polymorphism of Acid Phosphatase, Esterases, and Glutamate and Malate Dehydrogenases
}

\author{
By Ph. GOULLET*† AND B. PICARD \\ Laboratoire de Microbiologie, Faculté de Médecine Xavier Bichat (Université Paris VIn), \\ 16 rue Henri Huchard, 75018 Paris, France
}

(Received 8 April 1987; revised 24 August 1987)

\begin{abstract}
Acid phosphatase, esterases, and glutamate and malate dehydrogenases of 192 strains of Yersinia enterocolitica, $Y$. intermedia, $Y$. aldovae, $Y$. frederiksenii, $Y$. kristensenii and $Y$. pseudotuberculosis were analysed by horizontal polyacrylamide agarose gel electrophoresis and by isoelectrofocusing in thin-layer polyacrylamide gels. The six species were clearly separated from each other by their distinct enzyme electrophoretic polymorphism. For Y. enterocolitica, the strains of biotype 5 were differentiated from the other biotypes by the mobility of glutamate dehydrogenase. For $Y$. frederiksenii, six zymotypes were delineated by $\mathrm{pI}$ and by the mobility of the enzymes. Variation in number or mobility of esterases within each species could represent a marker for epidemiological and ecological analyses. A linear relationship was obtained between the mean genetic diversity coefficient of enzymes and the mean percentage DNA-DNA relatedness of $Y$. intermedia, $Y$. aldovae, $Y$. enterocolitica and $Y$. frederiksenii.
\end{abstract}

\section{INTRODUCTION}

The genus Yersinia consists of seven different species: Y. pseudotuberculosis, Y. enterocolitica, $Y$. intermedia, Y. frederiksenii, Y. kristensenii, Y. ruckeri (Bercovier \& Mollaret, 1984) and Y. aldovae (Bercovier et al., 1984). However, Y. ruckeri may constitute a new genus .

$Y$. enterocolitica and $Y$. pseudotuberculosis have been clearly characterized by the distinctive electrophoretic patterns of their esterases. In $Y$. enterocolitica, five principal zymotypes were delineated: zymotypes A and B for strains of biotype 1, zymotypes C and D for strains of biotypes 2 and 3, respectively, and zymotype E for strains of biotype 4 or biotype 5 (Goullet \& Picard, 1984a). Y. intermedia (Brenner et al., 1980b), Y. frederiksenii (Ursing et al., 1980), Y. kristensenii (Bercovier et al., 1980) and Y. aldovae (Bercovier et al., 1984), previously described as $Y$. enterocolitica-like organisms, isolated mainly from various environmental sources (water, fish, foods), were clearly distinguished from $Y$. enterocolitica sensu stricto by DNA-DNA hybridization (Brenner et al., 1980a; Bercovier et al., 1984). However, the phenotypic characterization based, for some species, on a limited number of conventional biochemical tests required the analysis of primary gene products.

By analysis of electrophoretic polymorphism of acid phosphatase (AP), esterases, and malate and glutamate dehydrogenases (MDH and GDH), the present work establishes specific and intra-specific differentiation of the six Yersinia species.

\footnotetext{
† Address for correspondence: Laboratoire de Microbiologie, Hôpital Beaujon, 100 Boulevard de General Leclerc, 92118 Clichy, France.

Abbreviations: AP, acid phosphatase; DFP, di-isopropyl fluorophosphate; GDH, glutamate dehydrogenase; IEF, isoelectrofocusing; $M_{F}$ electrophoretic mobility; $\mathrm{MDH}$, malate dehydrogenase.
} 


\section{Table 1. Strains examined}

CNY, Collection de Centre National et Centre Collaborateur OMS pour les Yersinia (Professor H. H. Mollaret), Institut Pasteur, Paris, France; CIP, Collection Institut Pasteur; ATCC, American Type Culture Collection, USA; CDC, Center for Diseases Control, USA.

Yersinia enterocolitica

\begin{tabular}{|c|c|c|c|}
\hline $\begin{array}{l}\text { Laboratory } \\
\text { code }\end{array}$ & $\begin{array}{c}\text { Strain } \\
\text { designation }\end{array}$ & $\begin{array}{l}\text { Bio- } \\
\text { type }\end{array}$ & Source \\
\hline $1,3,7,8$ & $\begin{array}{l}\text { CNY 6168, } \\
6155,6554, \\
6166\end{array}$ & 1 & Sewage, Denmark \\
\hline $2,5,6$ & $\begin{array}{r}\text { CNY 5919, } \\
6551,6552\end{array}$ & 1 & Wild rodent, France \\
\hline 4 & CNY 5429 & 1 & Hen, Poland \\
\hline 9 & CNY 7333 & 1 & $\begin{array}{l}\text { Milk, } \\
\text { Czechoslovakia }\end{array}$ \\
\hline 10 & CNY 842 & 1 & Human throat, USA \\
\hline 11 & CNY 7309 & 1 & Czechoslovakia \\
\hline $12,13,17$ & $\begin{array}{l}\text { CNY 2, 3, } \\
517\end{array}$ & 5 & Hare, France \\
\hline 14 & CNY 1144 & 5 & Hare, Belgium \\
\hline 15 , & $\begin{array}{l}\text { CNY } 2879, \\
2880\end{array}$ & 5 & Goat, Norway \\
\hline
\end{tabular}

Yersinia intermedia

\begin{tabular}{ccl}
$\begin{array}{c}\text { Laboratory } \\
\text { code }\end{array}$ & $\begin{array}{c}\text { Strain } \\
\text { designation }\end{array}$ & \multicolumn{1}{c}{ Source } \\
1 & CNY 8301 & Drinking water, Norway \\
$2,5,6,10$, & CNY 6237, & Sewage, Denmark \\
16,25 & 6187,5983, & \\
& 6194,6191, & \\
& 6151 & \\
3,15 & CNY 8870, & Drinking water, Italy \\
4 & 8871 & \\
7 & CNY 5630 & Hen stool, France \\
$8,9,11,17$ & CNY, 8771, & Drinking water, \\
& 8772,8770, & Czechoslovakia \\
& 8773 & \\
12,13 & CNY 8575, & Water, France \\
14 & 8576 & \\
18 & CNY 8713 & Human stool, USA \\
19,20 & CNY 955 & Water, Norway \\
& CNY 6249, & Pig, Denmark \\
21 & 6250 & \\
& CNY 8877 & Human blood, South \\
22,23 & CNY 5797, & Human blood, France \\
& 6030 & \\
24 & CNY 3953 & Human, USA \\
& (CIP 80.28, & \\
& ATCC & \\
& $29909)$ & \\
& &
\end{tabular}

\section{METHODS}

Bacterial strains. The test strains were the 53 strains of $Y$. enterocolitica and the 30 strains of $Y$. pseudotuberculosis previously analysed for their esterase patterns (Goullet \& Picard, 1984a) together with 109 new strains listed in Table 1. Bacteria were grown in Fernbach flasks containing $500 \mathrm{ml} \mathrm{L}$ broth (Lennox, 1955). Flasks were shaken vigorously at $28^{\circ} \mathrm{C}$ for $18 \mathrm{~h}$.

Electrophoresis. Protein extracts were prepared and analysed as described previously (Goullet \& Picard, 1984a, $1985 a$ ). Electrophoretic mobility ( $M_{F}$ value), isoelectrofocusing (IEF), esterase staining and the determination of correspondence between the two electrophoretic techniques were estimated using published procedures (Goullet \& Picard, 1984a, 1985a).

Enzyme tests and substrates. For esterases, the substrates used were $\alpha$-and $\beta$-naphthyl acetates, $\alpha$ - and $\beta$-naphthyl butyrates and indoxyl acetate. Inhibition by di-isopropyl fluorophosphate (DFP) was estimated as previously described (Goullet, 1980). GDH activity was detected by the method of Baptist et al. (1969), MDH activity by the method of Siciliano \& Shaw (1976) and AP activity according to Uriel (1963).

\section{RESULTS}

\section{Characterization of enzyme bands}

Polyacrylamide agarose gel electrophoresis. MDH and GDH each gave a single, well-stained band whereas AP was not detected. Nine principal kinds of esterase bands were defined by their activities toward synthetic substrates and their sensitivity or resistance to DFP. Six of these $\left(\mathrm{E}_{1}\right.$, $E_{2}, E_{6}, E_{7}, E_{\alpha a}$ and $E_{1 \alpha b}$ ) were similar to the corresponding bands of $Y$. enterocolitica (Goullet \& Picard, 1984a). Esterase $\mathrm{E}_{1}$ was faint for all strains of $Y$. intermedia and for some strains of $Y$. frederiksenii and $Y$. kristensenii. Three other esterases, designated as bands $\mathrm{E}_{\beta \mathrm{R}}, \mathrm{E}_{\alpha c}$ and $\mathrm{E}_{\mathrm{BA}}$, 
Table 1 (continued)

\begin{tabular}{|c|c|c|c|c|c|}
\hline \multicolumn{3}{|c|}{ Yersinia frederiksenii } & \multicolumn{3}{|c|}{ Yersinia kristensenii } \\
\hline $\begin{array}{l}\text { Laboratory } \\
\text { code }\end{array}$ & $\begin{array}{c}\text { Strain } \\
\text { designation }\end{array}$ & Source & $\begin{array}{l}\text { Laboratory } \\
\text { code }\end{array}$ & $\begin{array}{c}\text { Strain } \\
\text { designation }\end{array}$ & Source \\
\hline $\begin{array}{r}1,2,3,8,9 \\
10,11,14\end{array}$ & $\begin{array}{c}\text { CNY 5975, } \\
5960,5966, \\
5982,6150, \\
5981,6175\end{array}$ & Sewage, Denmark & $1,3,4,5,6$ & $\begin{array}{l}\text { CNY 5874, } \\
5878,5873 \text {, } \\
6072,5894, \\
5520\end{array}$ & Wild rodent stool, France \\
\hline & $\begin{array}{l}\text { (CIP } \\
80.29)\end{array}$ & & 2,20 & $\begin{array}{l}\text { CNY } 1474, \\
1475\end{array}$ & Water, Norway \\
\hline & 5976 & & 7 & CNY 103 & Sheep, Faroe Island \\
\hline 4,6 & $\begin{array}{l}\text { CNY 8718, } \\
8721\end{array}$ & Human stool, USA & 8 & CNY 8782 & $\begin{array}{l}\text { Drinking water, } \\
\text { Czechoslovakia }\end{array}$ \\
\hline 5 & CNY 8684 & Human stool, FRG & 9 & CNY 6048 & Human stool, Australia \\
\hline $\begin{array}{l}7 \\
12,13\end{array}$ & $\begin{array}{l}\text { CNY } 6334 \\
\text { CNY } 8801\end{array}$ & $\begin{array}{l}\text { Human blood, France } \\
\text { Rat, Czechoslovakia }\end{array}$ & 10,14 & $\begin{array}{l}\text { CNY 8346, } \\
8347\end{array}$ & Human stool, France \\
\hline & 8797 & & 11 & CNY 8680 & Human stool, FRG \\
\hline 15 & CNY 867 & Human stool, Belgium & 12 & CNY 490 & Hare spleen, France \\
\hline 16,17 & $\begin{array}{l}\text { CNY 8824, } \\
8826\end{array}$ & Dog stool, Brazil & $\begin{array}{l}13 \\
15\end{array}$ & $\begin{array}{l}\text { CNY } 3605 \\
\text { CNY } 105\end{array}$ & $\begin{array}{l}\text { Monkey stool, Japan } \\
\text { Human urine, Denmark }\end{array}$ \\
\hline 18 & CNY 8849 & Human, France & 16 & CNY 5553 & Water, Czechoslovakia \\
\hline 19,20 & $\begin{array}{l}\text { CNY 8786, } \\
8787\end{array}$ & $\begin{array}{l}\text { Drinking water, } \\
\text { Czechoslovakia }\end{array}$ & 18,19 & $\begin{array}{l}\text { CNY } 8711, \\
8712\end{array}$ & Human stool, USA \\
\hline & & & 21 & CNY 5591 & $\begin{array}{l}\text { Wild rodent spleen, } \\
\text { France }\end{array}$ \\
\hline
\end{tabular}

Laboratory code

$1,2,12,13,20,21$,

$22,23,24,26$

$3,4,5,7,9,18$

$6,8,10,19$

11,16

$14,15,25$

17
Yersinia aldovae

Strain designation

CNY 7927, 7928, 7971, 7970, 8286,

8288, 8285, 8290, 8287, 7898

CNY 6005 (CDC 669.83, ATCC 35236), 6679, 7092, 7328, 7090, 7091

CNY 7331, 7089, 7111, 7112

CNY 7683, 7109

CNY 7618, 7622, 7632

CNY 7096

\author{
Source \\ Water, Norway \\ Drinking water, Czechoslovakia \\ Surface water, Czechoslovakia \\ Water, Czechoslovakia \\ Fish, Norway \\ River, Czechoslovakia
}

were clearly distinguished. Band $\mathrm{E}_{\beta \mathrm{R}}$ hydrolysed only $\beta$-naphthyl acetate. Band $\mathrm{E}_{\alpha c}$ degraded $\alpha$ naphthyl acetate and butyrate. Band $\mathrm{E}_{\mathrm{BA}}$ hydrolysed butyryl esters and, to a lesser degree, acetyl esters. Esterase $E_{B A}$ was sensitive to $10^{-3} \mathrm{M}$-DFP whereas esterases $E_{\beta R}$ and $E_{\alpha c}$ were resistant to this agent.

$I E F$. Satisfactory resolution with distinct banding was obtained for $\mathrm{MDH}$ and AP. The latter enzyme could not be detected in Y. pseudotuberculosis. GDH was not detected. MDH gave a well-stained major band (used for pI determination) and two or three anodic satellite bands when a narrow $\mathrm{pH}$ range from 4 to 6.5 was used. AP gave a major band when a narrow $\mathrm{pH}$ range from 8 to 10.5 was used. For esterases, the best results were obtained with $\beta$-naphthyl acetate as substrate. Only four esterases (bands $E_{1}, E_{B A}, E_{\beta R}$ and $E_{7}$ ) were detected using two narrow $\mathrm{pH}$ gradients (4 to 6.5 and 5 to 8 ). The four enzymes gave sharp, faintly stained bands which were used for pI determination.

\section{Range of $p I$ and mobilities of enzyme bands among the strains}

The electrophoretic relationships between the strains were established by numerous replicate runs comparing enzyme bands side by side on the same gel. The reproducibility of the results was confirmed as described by Picard \& Goullet (1985).

$Y$. enterocolitica. (Tables 2 and 3.) MDH had the same pI and mobility values in all strains. GDH had an identical $M_{F}$ value in strains of biotypes 1 to 4 but a distinct value in biotype 5 . 
Table 2. pI and $M_{F}$ values of enzyme bands in $Y$. enterocolitica and $Y$. pseudotuberculosis

The 53 strains of $Y$. enterocolitica and the 30 strains of $Y$. pseudotuberculosis were those previously analysed for their esterase patterns (Goullet \& Picard, 1984a).

$\begin{array}{cccc}\begin{array}{c}\text { Species } \\ \text { Y. enterocolitica } \\ \text { Biotype 1 }\end{array} & \begin{array}{c}\text { MDH } \\ \left(\mathrm{pI} / \boldsymbol{M}_{\boldsymbol{F}}\right)\end{array} & \begin{array}{c}\text { GDH } \\ \left(M_{F}\right)\end{array} & \begin{array}{c}\text { AP } \\ (\mathrm{pI})\end{array} \\ & & & \\ \text { Biotype 2 } & 5 \cdot 75 / 36 & 16 & 8 \cdot 5 \\ \text { Biotype 3 } & 5 \cdot 75 / 36 & 16 & 8 \cdot 7 \\ \text { Biotype 4 } & 5 \cdot 75 / 36 & 16 & 8 \cdot 7 \\ \text { Biotype 5 } & 5 \cdot 75 / 36 & 16 & 8 \cdot 7 \\ \text { Y. pseudotuberculosis } & 5 \cdot 75 / 36 & 16 & 8 \cdot 7 \\ & 5 \cdot 75 / 36 & 17 & 8 \cdot 7 \\ & 5 \cdot 8 / 42 & 17 & -\end{array}$

Table 3. $p I$ and $M_{F}$ values of enzyme bands in the 17 new strains of $Y$. enterocolitica The $\mathrm{pI} / M_{F}$ for $\mathrm{MDH}$ was $5 \cdot 75 / 36$ for all strains.

\begin{tabular}{lccccccccc}
\multicolumn{1}{c}{ Strain code } & $\begin{array}{c}\mathrm{GDH} \\
\left(\boldsymbol{M}_{F}\right)\end{array}$ & $\begin{array}{c}\mathrm{AP} \\
(\mathrm{pI})\end{array}$ & $\begin{array}{c}\mathrm{E}_{1} \\
\left(\boldsymbol{M}_{F}\right)\end{array}$ & $\begin{array}{c}\mathrm{E}_{2} \\
\left(\boldsymbol{M}_{F}\right)\end{array}$ & $\begin{array}{c}\mathrm{E}_{3} \\
\left(M_{F}\right)\end{array}$ & $\begin{array}{c}\mathrm{E}_{4} \\
\left(\boldsymbol{M}_{F}\right)\end{array}$ & $\begin{array}{c}\mathrm{E}_{5} \\
\left(M_{F}\right)\end{array}$ & $\begin{array}{c}\mathrm{E}_{6} \\
\left(M_{F}\right)\end{array}$ & $\begin{array}{c}\mathrm{E}_{7} \\
\left(M_{F}\right)\end{array}$ \\
1 & 16 & $8 \cdot 7$ & 82 & 65 & 55 & 47 & 20 & -7 & 73 \\
2 & 16 & $8 \cdot 7$ & 82 & 65 & 55 & 47 & 20 & -7 & - \\
4 & 16 & $8 \cdot 7$ & 78 & 65 & 55 & 47 & 20 & -7 & 75 \\
$5,6,7$ & 16 & $8 \cdot 7$ & 78 & 65 & 55 & 47 & 20 & -7 & 73 \\
8 & 16 & $8 \cdot 7$ & 78 & 65 & 55 & 47 & 20 & -7 & 70 \\
9 & 16 & $8 \cdot 7$ & 78 & 65 & 55 & 47 & 20 & -7 & - \\
10 & 16 & $8 \cdot 5$ & 82 & 65 & 60 & 47 & 22 & -7 & 78 \\
11 & 16 & $8 \cdot 5$ & 82 & 65 & 60 & 47 & 22 & -7 & 75 \\
$12,13,14,15,16$ & 16 & $8 \cdot 5$ & 78 & 65 & 60 & 47 & 22 & -7 & 75 \\
17 & 17 & $8 \cdot 7$ & 80 & 63 & - & 46 & - & -20 & 70 \\
& 17 & $8 \cdot 7$ & 80 & 63 & - & 46 & - & -5 & 70
\end{tabular}

Acid phosphatase was monomorphic with the exception of strains from zymotype B (Goullet \& Picard, 1984a), in which it focused at pH 8.5. The 11 new strains of biotype 1 and the six new strains of biotype 5 exhibited the same esterase electrophoretic pattern as the strains analysed previously (Goullet \& Picard, 1984a).

$Y$. pseudotuberculosis. (Table 2.) MDH has identical pI and $M_{F}$ values and GDH an identical $M_{F}$ value for all strains. AP was not detected.

$Y$. intermedia. (Table 4.) MDH and GDH were monomorphic in all strains. AP focused at $\mathrm{pH} 9.75$ except for strains 6 and 22 where it focused at $\mathrm{pH} 8.8$ and $\mathrm{pH} 9.8$, respectively. Esterases $E_{1}, E_{\beta R}$ and $E_{B A}$ were detected in all strains. Bands $E_{2}$ and $E_{\alpha \mathrm{a}}$ were detected in the majority of strains and band $E_{7}$ was detected in only seven strains. Esterase $E_{2}$ showed two bands. Band $B_{2}$ was replaced by band $E_{\alpha b}$ in strain 22 . Esterases $E_{1}$ and $E_{7}$ showed one type of mobility, esterases $\mathrm{E}_{2}$ and $\mathrm{E}_{\beta \mathrm{R}}$ showed two types and esterases $\mathrm{E}_{\mathrm{BA}}$ and $\mathrm{E}_{\alpha \mathrm{a}}$ showed three types of mobility. Strain 1 had an additional band at $M_{F} \approx 76$ for esterase $\mathrm{E}_{\mathrm{BA}}$. The $\mathrm{pI}$ of esterases $\mathrm{E}_{\beta \mathrm{R}}$ and $\mathrm{E}_{\mathrm{BA}}$ were respectively 5.35 and 6.4 for all strains.

$Y$. aldovae. (Table 5.) MDH and GDH were monomorphic in all strains whereas AP was polymorphic with four distinct $\mathrm{pI}$ values ranging from $9 \cdot 1$ to $9 \cdot 7$. Esterase bands $E_{1}$ and $E_{\beta R}$ were detected in all strains (except esterase $E_{\beta \mathbf{R}}$ for strain 1). Esterase $E_{1}$ had a pI value of 5 but showed four types of mobility. Most strains (22) had esterase $\mathrm{E}_{1}$ at $M_{F} \approx 82$. In strain 24 , band $E_{\alpha \mathrm{a}}$ was replaced by esterase $E_{\alpha \mathrm{b}}$. Esterase $E_{\beta \mathrm{R}}$ had the same mobility in strains 2 to 25 but showed several $\mathrm{pI}$ values ranging from $6 \cdot 1$ to 6.35 . Strain 2 possessed an additional band at $M_{F} \approx 26$. In strain 26 the mobility of $\mathrm{E}_{\beta \mathrm{R}}$ was $M_{F} \approx 65$ and the $\mathrm{pI}$ was $5 \cdot 7$. Band $\mathrm{E}_{6}$ was observed in strains 16 to 25 and band $E_{7}$ in strains 1 to 15 . Strain 1 showed two bands for esterase $E_{7}$. 
Table 4. $p I$ and $M_{F}$ values of enzyme bands in strains of $Y$. intermedia

For all strains the $\mathrm{pI} / M_{F}$ for $\mathrm{MDH}$ was $5 \cdot 75 / 36$, the $M_{F}$ of GDH was 18 , and the $M_{F}$ of $\mathrm{E}_{1}$ was 82 .

\begin{tabular}{|c|c|c|c|c|c|c|}
\hline Strain code & $\begin{array}{l}\mathrm{AP} \\
(\mathrm{pI})\end{array}$ & $\begin{array}{c}\mathrm{E}_{2} \\
\left(M_{F}\right)\end{array}$ & $\begin{array}{c}\mathrm{E}_{7} \\
\left(M_{F}\right)\end{array}$ & $\begin{array}{c}\mathrm{E}_{\alpha \mathrm{a}} \\
\left(\boldsymbol{M}_{\boldsymbol{F}}\right)\end{array}$ & $\begin{array}{c}\mathrm{E}_{\beta \mathrm{R}} \\
\left(M_{F}\right)\end{array}$ & $\begin{array}{l}\mathrm{E}_{\mathrm{BA}} \\
\left(M_{F}\right)\end{array}$ \\
\hline 1 & $9 \cdot 75$ & $63 / 66$ & 16 & - & 48 & $30 / 76$ \\
\hline 2,3 & 9.75 & $63 / 66$ & 16 & - & 48 & 30 \\
\hline 4,5 & 9.75 & $63 / 66$ & 16 & 77 & 48 & 30 \\
\hline 6 & $8 \cdot 8$ & $63 / 66$ & 16 & 77 & 48 & 30 \\
\hline 7 & $9 \cdot 75$ & $64 / 68$ & 16 & 77 & 48 & 30 \\
\hline 8,9 & 9.75 & $64 / 68$ & - & 77 & 48 & 30 \\
\hline $10,11,12,13,14$ & 9.75 & $63 / 66$ & - & 77 & 48 & 30 \\
\hline $15,16,17,18,19,20$ & 9.75 & $63 / 66$ & - & 76 & 48 & 30 \\
\hline 21 & 9.75 & $63 / 66$ & - & 76 & 46 & 30 \\
\hline 22 & $9 \cdot 8$ & $63^{*}$ & - & 75 & 48 & 30 \\
\hline 23,24 & 9.75 & $63 / 66$ & - & 75 & 48 & 32 \\
\hline 25 & 9.75 & - & - & 75 & 48 & 32 \\
\hline
\end{tabular}

* In strain 22 , esterase $E_{2}$ was replaced by esterase $E_{a b}$.

Table 5. $p I$ and $M_{F}$ values of enzyme bands in strains of $Y$. aldovae

For all strains the $\mathrm{pl} / \boldsymbol{M}_{F}$ for $\mathrm{MDH}$ was $5.75 / 36$, and the $\boldsymbol{M}_{F}$ of $\mathrm{GDH}$ was 14 .

$\begin{array}{llcccccc}\text { Strain code } & \begin{array}{c}\mathrm{AP} \\ (\mathrm{pI})\end{array} & \begin{array}{c}\mathrm{E}_{1} \\ \left(\boldsymbol{M}_{\boldsymbol{F}}\right)\end{array} & \begin{array}{c}\mathrm{E}_{2} \\ \left(\boldsymbol{M}_{\boldsymbol{F}}\right)\end{array} & \begin{array}{c}\mathrm{E}_{6} \\ \left(\boldsymbol{M}_{\boldsymbol{F}}\right)\end{array} & \begin{array}{c}\mathrm{E}_{7} \\ \left(\boldsymbol{M}_{\boldsymbol{F}}\right)\end{array} & \begin{array}{c}\mathrm{E}_{\alpha \mathrm{a}} \\ \left(\boldsymbol{M}_{F}\right)\end{array} & \begin{array}{c}\mathrm{E}_{\beta \mathrm{R}} \\ \left(\boldsymbol{M}_{F}\right)\end{array} \\ 1 & 9 \cdot 5 & 78 & - & - & 16 / 26 & - & - \\ 2 & 9 \cdot 35 & 79 & 64 & - & 16 & - & 26 / 44 \\ 3,4,5,6,7 & 9 \cdot 5 & 82 & - & - & 16 & 78 & 44 \\ 8,9,10,11 & 9 \cdot 5 & 82 & 79 & - & 16 & - & 44 \\ 12 & 9 \cdot 5 & 82 & - & - & 16 & 79 & 44 \\ 13 & 9 \cdot 5 & 82 & - & - & 16 & 82 & 44 \\ 14 & 9 \cdot 5 & 82 & 64 / 70 & - & 10 & 81 & 44 \\ 15 & 9 \cdot 5 & 82 & - & - & 10 & 79 & 44 \\ 16,17,18 & 9 \cdot 5 & 82 & - & -7 & - & 78 & 44 \\ 19 & 9 \cdot 7 & 82 & - & -7 & - & 78 & 44 \\ 20,21 & 9 \cdot 5 & 82 & 75 & -7 & - & 78 & 44 \\ 22 & 9 \cdot 7 & 82 & 75 & -7 & - & 78 & 44 \\ 23 & 9 \cdot 5 & 82 & 64 & -7 & - & 78 & 44 \\ 24 & 9 \cdot 5 & 82 & 75 & -7 & - & 78^{*} & 44 \\ 25 & 9 \cdot 35 & 84 & 64 / 58 & -7 & - & 80 & 44 \\ 26 & 9 \cdot 1 & 84 & - & - & - & 81 & 65\end{array}$

* In strain 24 , esterase $E_{\alpha a}$ was replaced by esterase $E_{\alpha b}$.

$Y$. frederiksenii. (Table 6.) $\mathrm{MDH}, \mathrm{GDH}$ and AP were polymorphic and could serve to delineate six zymotypes. $\mathrm{MDH}$ had the same $\mathrm{pI}$ and $M_{F}$ values in strains of zymotypes $\mathrm{F}_{1}$ to $\mathrm{F}_{4}$ and was distinct in strains of zymotype $F_{5}$ and $F_{6}$. GDH was identical for strains of zymotypes $F_{2}$ and $F_{3}$ but distinct for each of the other zymotypes. AP distinguished zymotype $F_{2}$ from zymotype $\mathrm{F}_{3}$. This delineation of six zymotypes was confirmed by the $M_{F}$ values of esterase $\mathrm{E}_{\alpha \mathrm{a}}$, by the $M_{F}$ and $\mathrm{pI}$ values of esterases $\mathrm{E}_{1}$ and $\mathrm{E}_{7}$ and by the occurrence in some strains of additional esterases. Zymotype $F_{1}$ was distinguished from zymotype $F_{2}$ by a difference in $\mathrm{pI}$ and esterase $\mathrm{E}_{1}$ mobility (pI $5 / M_{F} \approx 84$ and $\mathrm{pI} 4 \cdot 9 / M_{F} \approx 87$, respectively) and the presence of bands $\mathrm{E}_{\beta \mathrm{R}}$ and $\mathrm{E}_{\alpha c}\left(M_{F} \approx 34\right.$ ). Zymotypes $\mathrm{F}_{3}$ and $\mathrm{F}_{4}$ had the same $\mathrm{pI}$ and mobility for esterase $\mathrm{E}_{1}$ (pI $\left.4 \cdot 85 / M_{F} \approx 90\right)$ but differed in the $\mathrm{pI}$ and mobility of esterase $\mathrm{E}_{7}\left(\mathrm{pI} 6.5 / M_{F} \approx 8\right.$ and $\mathrm{pI}$ $6 \cdot 4 / M_{F} \approx 16$, respectively). Moreover, strains of zymotype 5 showed esterase $\mathrm{E}_{\alpha \mathrm{a}}$ at $M_{F} \approx 80$ and band $E_{7}$ at pl 5.9 and $M_{F} \approx 42$ and produced three additional esterases $\left(M_{F} \approx 67,64\right.$ and 53 ), which hydrolysed $\alpha$-naphthyl, $\beta$-naphthyl and indoxyl acetates, respectively. The first two were faint and sensitive to DFP and the third was resistant to DFP. Strains of zymotype 6 did not show esterases $E_{\alpha \mathrm{a}}$ and $\mathrm{E}_{7}$ but produced an additional esterase designated as band $\mathrm{E}_{\mathrm{AB}}$ which hydrolysed the five substrates, was sensitive to DFP and migrated at $M_{F} \approx 64$. 
Table 6. pI and $M_{F}$ values of enzyme bands in strains of $Y$. frederiksenii

\begin{tabular}{|c|c|c|c|c|c|c|c|c|c|c|}
\hline & $\begin{array}{c}\text { Strain } \\
\text { code }\end{array}$ & $\underset{\left(\mathrm{pI} / M_{F}\right)}{\mathrm{MDH}}$ & $\begin{array}{c}\text { GDH } \\
\left(M_{F}\right)\end{array}$ & $\underset{(\mathrm{pI})}{\mathrm{AP}}$ & $\begin{array}{c}\mathrm{E}_{1} \\
\left(M_{F}\right)\end{array}$ & $\begin{array}{c}\mathrm{E}_{2} \\
\left(M_{F}\right)\end{array}$ & $\begin{array}{c}\mathrm{E}_{7} \\
\left(M_{F}\right)\end{array}$ & $\begin{array}{c}\mathrm{E}_{\alpha \mathrm{a}} \\
\left(M_{F}\right)\end{array}$ & $\begin{array}{c}\mathrm{E}_{\alpha \mathrm{b}} \\
\left(M_{F}\right)\end{array}$ & $\begin{array}{c}\mathrm{E}_{\beta \mathrm{R}} \\
\left(M_{F}\right)\end{array}$ \\
\hline Zymotype $F_{1}$ & $\begin{array}{l}1 \\
2 \\
3 \\
4 \\
5 \\
6 \\
7,8,9,10\end{array}$ & $\begin{array}{l}5 \cdot 8 / 36 \\
5 \cdot 8 / 36 \\
5 \cdot 8 / 36 \\
5 \cdot 8 / 36 \\
5 \cdot 8 / 36 \\
5 \cdot 8 / 36 \\
5 \cdot 8 / 36\end{array}$ & $\begin{array}{l}17 \\
17 \\
17 \\
17 \\
17 \\
17 \\
17\end{array}$ & $\begin{array}{l}9 \cdot 5 \\
9 \cdot 5 \\
9 \cdot 5 \\
9 \cdot 5 \\
9 \cdot 45 \\
9 \cdot 5 \\
9 \cdot 5\end{array}$ & $\begin{array}{l}84 \\
84 \\
84 \\
84 \\
84 \\
84 \\
84\end{array}$ & $\begin{array}{l}59 \\
- \\
59 \\
- \\
59 \\
59 \\
64\end{array}$ & $\begin{array}{c}16 \\
15 \\
16 \\
16 \\
- \\
16 \\
8\end{array}$ & $\begin{array}{l}- \\
74 \\
74 \\
74 \\
74 \\
74 \\
74\end{array}$ & $\begin{array}{l}69 \\
69 \\
69 \\
69 \\
69 \\
69 \\
-\end{array}$ & $\begin{array}{l}48 \\
48 \\
48 \\
48 \\
- \\
- \\
48\end{array}$ \\
\hline Zymotype $F_{2}$ & $\begin{array}{l}11 \\
12,13\end{array}$ & $\begin{array}{l}5 \cdot 8 / 36 \\
5 \cdot 8 / 36\end{array}$ & $\begin{array}{l}16 \\
16\end{array}$ & $\begin{array}{l}8.8 \\
8.8\end{array}$ & $\begin{array}{l}87 \\
87\end{array}$ & $\begin{array}{l}65 \\
64\end{array}$ & $\begin{array}{l}8 \\
8\end{array}$ & $\begin{array}{l}74 \\
74\end{array}$ & - & - \\
\hline Zymotype $F_{3}$ & 14 & $5 \cdot 8 / 36$ & 16 & $9 \cdot 35$ & 90 & 64 & 8 & 78 & - & - \\
\hline Zymotype $F_{4}$ & 15 & $5 \cdot 8 / 36$ & 14 & $8 \cdot 4$ & 90 & 64 & 16 & 78 & - & - \\
\hline Zymotype $\mathrm{F}_{5}$ & $16,17,18$ & $5 \cdot 3 / 42$ & 19 & $8 \cdot 8$ & 90 & - & 42 & 80 & - & - \\
\hline Zymotype $F_{6}$ & 19,20 & $5 \cdot 6 / 36$ & 18 & 9.75 & 84 & - & - & - & 59 & - \\
\hline
\end{tabular}

Table 7. $P I$ and $M_{F}$ values of enzyme bands in strains of $Y$. kristensenii

\begin{tabular}{|c|c|c|c|c|c|c|c|c|c|}
\hline $\begin{array}{l}\text { Strain } \\
\text { code }\end{array}$ & $\underset{\left(\mathrm{pI} / M_{F}\right)}{\mathrm{MDH}}$ & $\begin{array}{c}\text { GDH } \\
\left(M_{F}\right)\end{array}$ & $\begin{array}{l}\text { AP } \\
\text { (pI) }\end{array}$ & $\begin{array}{c}E_{1} \\
\left(M_{F}\right)\end{array}$ & $\begin{array}{c}\mathrm{E}_{2} \\
\left(M_{F}\right)\end{array}$ & $\begin{array}{c}\mathrm{E}_{6} \\
\left(M_{F}\right)\end{array}$ & $\begin{array}{c}\mathrm{E}_{7} \\
\left(M_{F}\right)\end{array}$ & $\begin{array}{c}\mathrm{E}_{\alpha \mathrm{a}} \\
\left(M_{F}\right)\end{array}$ & $\begin{array}{c}\mathrm{E}_{\mathrm{\alpha b}} \\
\left(M_{F}\right)\end{array}$ \\
\hline 1 & $5 \cdot 65 / 40$ & 21 & 9.5 & 82 & 68 & - & 16 & 77 & - \\
\hline 2 & $5 \cdot 65 / 36$ & 20 & 9.5 & 82 & 68 & - & 16 & 77 & - \\
\hline 3,4 & $5 \cdot 65 / 40$ & 20 & 9.5 & 82 & 68 & - & 16 & 77 & - \\
\hline 5 & $5.65 / 40$ & 20 & 9.5 & 82 & 68 & - & 15 & 77 & - \\
\hline 6 & $5 \cdot 65 / 40$ & 20 & 9.5 & 82 & 68 & -5 & - & 77 & - \\
\hline 7 & $5.65 / 40$ & 20 & 8.95 & 82 & $63^{*}$ & -5 & - & - & 63 \\
\hline 8 & $5.65 / 40$ & 20 & $9 \cdot 25$ & 82 & $68^{*}$ & -5 & - & - & $63 \ddagger$ \\
\hline 9 & $5.65 / 40$ & 20 & 8.4 & 82 & $68^{*}$ & -5 & - & 79 & $63 \ddagger$ \\
\hline 10 & $5.65 / 40$ & 20 & 8.95 & 82 & $68^{*}$ & -5 & - & 79 & $63 \ddagger$ \\
\hline 11 & $5.65 / 40$ & 20 & 8.95 & 82 & $70^{*}$ & -5 & - & 79 & $68 \ddagger$ \\
\hline 12 & $5.65 / 40$ & 20 & 8.95 & 82 & $70^{*}$ & -5 & - & $79 \dagger$ & - \\
\hline 13 & $5.65 / 40$ & 20 & 8.95 & 82 & $70^{*}$ & -5 & - & - & - \\
\hline 14 & $5 \cdot 65 / 40$ & 21 & 8.95 & 82 & $60^{*}$ & - & 16 & $68+$ & - \\
\hline 15 & $5 \cdot 65 / 36$ & 20 & 8.95 & 82 & $60^{*}$ & - & 16 & $68 \dagger$ & - \\
\hline 16 & $5.65 / 40$ & - & 8.95 & - & $62^{*}$ & - & 16 & $68+$ & - \\
\hline 17 & $5.65 / 40$ & 17 & 8.95 & 84 & $62^{*}$ & - & 16 & $68 \dagger$ & - \\
\hline 18,19 & $5 \cdot 65 / 40$ & 20 & 8.95 & 84 & $63^{*}$ & - & 16 & - & $72 \ddagger$ \\
\hline 20 & $5 \cdot 65 / 40$ & 20 & $8 \cdot 4$ & 84 & - & - & 16 & - & $70 \ddagger$ \\
\hline 21 & $5.65 / 36$ & 20 & 8.95 & - & $60^{*^{*}}$ & - & 16 & $70 \dagger$ & - \\
\hline
\end{tabular}

Y. kristensenii. (Table 7.) MDH which had the same pI value for all strains, had two mobility values. GDH and AP were polymorphic with three mobility values and four pI values, respectively. Esterase bands may be divided according to their mobilities. The slow moving esterases corresponded to band $\mathrm{E}_{7}$ or $\mathrm{E}_{6}$ which migrated at $M_{F} \approx 16$ or $M_{F} \approx-5$, respectively and were detected in all strains. In strains 1 to 6 , the fast moving bands consisted of esterases $E_{1}$, $E_{\alpha \mathrm{a}}$ and $E_{2}$, and an esterase designated band $E_{B}$; this esterase hydrolysed butyryl ester and to a lesser degree the other substrates, was resistant to DFP and migrated at $M_{F} \approx 60$. These fast bands all showed identical mobilities in the six strains. In the other strains ( 7 to 21$)$ the fast bands varied considerably in number and in the type of esterase activity. Some bands were unambiguously identified as esterases $\mathrm{E}_{1}$ and $\mathrm{E}_{\alpha \mathrm{a}}$, whereas atypical bands, designated as $\mathrm{E}_{\alpha \mathrm{a}}^{\prime}, \mathrm{E}_{\alpha \mathrm{b}}^{\prime}$ and $E_{2}^{\prime}$, differed from esterases $E_{\alpha a}, E_{\alpha b}$ and $E_{2}$, respectively, in their hydrolysing properties and/or their sensitivity to DFP (results not shown). Additionally, an esterase band similar to 
esterase $\mathrm{E}_{\mathrm{AB}}$ of $Y$. frederiksenii was detected in strains 15 to 19 and was polymorphic with three mobility values ranging from $M_{F} \approx 77$ to $M_{F} \approx 82$.

\section{DISCUSSION}

Polyacrylamide agarose gel electrophoresis and IEF were complementary for the detection of GDH and $A P$ activities. Only $A P, M D H$ and esterases $E_{1}, E_{A B}, E_{\beta R}$ and $E_{7}$ were resolved by IEF. The lower resolving power of IEF for detecting enzyme activity, which had previously been observed for some esterases and other enzymes (Goullet \& Picard, 1985b, 1986; Picard \& Goullet, 1985), may be caused by interaction between carrier ampholytes and proteins or by denaturation of these enzymes at acidic pI values. Thus, titration curves of GDH (Picard et al., 1987) demonstrated the $\mathrm{pH}$ sensitivity of this enzyme at its isoelectric point, as has been previously observed for other bacterial species. The fact that AP was not resolved in polyacrylamide agarose gel electrophoresis at $\mathrm{pH} 8.6$ could be explained by its alkaline $\mathrm{pI}$ values (from 8.4 to 9.75 ). The two electrophoretic procedures were complementary in their resolution of enzyme polymorphism. Thus, the number of $\mathrm{MDH}$ variants detected by polyacrylamide agarose gel electrophoresis, IEF and a combination of the two techniques was three, five and seven, respectively. Twelve distinct esterase bands were resolved in cellular extracts of $Y$. intermedia, $Y$. aldovae, $Y$. frederiksenii and $Y$. kristensenii. Six esterase bands were similar to those of $Y$. enterocolitica (Goullet \& Picard, 1984a). Two major kinds of esterases not detected in $Y$. enterocolitica and $Y$. pseudotuberculosis were found in other Yersinia species: esterase $\mathrm{E}_{\mathrm{BA}}$ in $Y$. intermedia and esterase $\mathrm{E}_{\beta \mathrm{R}}$ in $Y$. aldovae, $Y$. intermedia and $Y$. frederiksenii. Esterases $\mathrm{E}_{\alpha c}, \mathrm{E}_{\mathrm{Al}}, \mathrm{E}_{\mathrm{B}}$ and $\mathrm{E}_{\mathrm{AB}}$ were detected in some strains of $Y$. frederiksenii and $Y$. kristensenii. Band $\mathrm{E}_{\mathrm{AB}}$ resembled esterases $\mathrm{E}_{3}$ and $\mathrm{E}_{5}$ of $Y$. enterocolitica in its hydrolysing activity and its sensitivity to DFP.

This work demonstrates that $Y$. enterocolitica, $Y$. intermedia, $Y$. aldovae, $Y$. frederiksenii, $Y$. kristensenii and $Y$. pseudotuberculosis may be characterized by the distinctive distribution of the electrophoretic bands of AP, MDH, GDH and esterases. These enzyme data appeared to be sufficient to identify to species level 192 recent isolates. Analysis of primary gene products therefore strongly supports the phenotypic characterization of the six species based on conventional biochemical tests (Bercovier \& Mollaret, 1984; Bercovier et al., 1984). The limited number of electrophoretic types characterized by AP, MDH and GDH within each species (Table 8 ) suggests that electrophoretic analysis of these enzymes can be used as a preliminary

Table 8. Number of enzyme electrophoretic types detected within the six species of Yersinia

\begin{tabular}{|c|c|c|c|}
\hline & $\begin{array}{c}\mathrm{AP}, \mathrm{MDH} \text { and GDH } \\
\text { electrophoretic } \\
\text { types* }\end{array}$ & $\begin{array}{c}\text { Esterase } \\
\text { electrophoretic } \\
\text { types } \dagger\end{array}$ & $\begin{array}{c}\text { Enzyme } \\
\text { electrophoretic } \\
\text { types } \$\end{array}$ \\
\hline $\begin{array}{l}\text { Y. enterocolitica } \\
\text { (70 strains) }\end{array}$ & 3 & 20 & 22 \\
\hline $\begin{array}{l}\text { Y. pseudotuberculosis } \\
\text { (30 strains) }\end{array}$ & 1 & 5 & 5 \\
\hline $\begin{array}{l}\text { Y. intermedia } \\
\text { (25 strains) }\end{array}$ & 3 & 11 & 12 \\
\hline $\begin{array}{l}\text { Y. aldovae } \\
\text { (26 strains) }\end{array}$ & 4 & 14 & 18 \\
\hline $\begin{array}{l}\text { Y. frederiksenii } \\
\text { (20 strains) }\end{array}$ & 7 & 13 & 14 \\
\hline $\begin{array}{l}Y . \text { kristensenii } \\
\text { (21 strains) }\end{array}$ & 10 & 17 & 19 \\
\hline
\end{tabular}




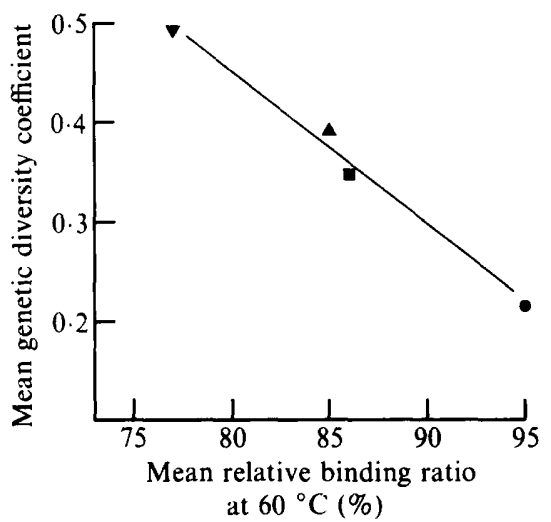

Fig. 1. Relationship between the mean genetic diversity coefficient of AP, MDH, GDH and esterases $\mathrm{E}_{\alpha \mathrm{a}}, \mathrm{E}_{1}$ and $\mathrm{E}_{6}-\mathrm{E}_{7}$ and the mean percentage DNA-DNA relatedness in $Y$. intermedia $(O)$, $Y$. aldovae ( $)$, Y. enterocolitica $(\boldsymbol{\Lambda})$ and $Y$. frederiksenii $(\boldsymbol{\nabla})$. For the four species, the mean relative binding ratio at $60^{\circ} \mathrm{C}$ was calculated from the data obtained by Brenner et al. (1980a) and Bercovier et al. (1984).

screening for species identification. Biochemical tests, $\mathrm{O}$ antigen determination, antibiotic and bacteriophage susceptibilities have been proposed for epidemiological or ecological analyses (Bercovier et al., 1978; Baker \& Farmer, 1982). However, the higher degree of electrophoretic polymorphism of esterases allows more precise identification of strains. Similar results have been obtained for Escherichia coli (Goullet \& Picard, 1984b), Aeromonas hydrophila (Picard \& Goullet, 1985) and Enterobacter sakazakii (Goullet \& Picard, 1986). The separation of zymotypes A and B of Y. enterocolitica (Goullet \& Picard, 1984a) was confirmed by differences in the pI values of their APs whereas biotypes 4 and 5 (unresolved by esterase mobility) were differentiated by GDH mobility. Strains of $Y$. kristensenii, which in some cases were hardly distinguishable by esterase electrophoretic patterns because of considerable variation in the number and kind of bands, were clearly characterized by the pI of their $\mathrm{MDH}$ and also by a combination of the mobility of GDH and the $\mathrm{pI}$ value of AP. Identification of the six zymotypes of $Y$. frederiksenii by $\mathrm{MDH}, \mathrm{GDH}$ and AP patterns was substantiated by esterase patterns. Strains of zymotypes $F_{5}$ and $F_{6}$ appeared to be dramatically different from each other and from other strains of $Y$. frederiksenii. These considerable molecular divergences suggest that the strains corresponding to these zymotypes are genetically very different from other $Y$. frederiksenii strains. This requires further studies including DNA-DNA hybridization. The strains of $Y$. intermedia (rhamnose, melibiose and $\alpha$-methyl-D-glycoside positive) (Brenner et al., $1980 \mathrm{~b}$ ) and $Y$. aldovae (rhamnose positive, sucrose, cellobiose and sorbose negative) (Bercovier et al., 1984), which are most biochemically distinct from $Y$. enterocolitica, appeared to have the most homogeneous enzyme electrophoretic patterns. In the species which are less biochemically distinct from $Y$. enterocolitica, i.e. $Y$. frederiksenii (rhamnose positive) (Ursing et al., 1980) and $Y$. kristensenii (Voges-Proskauer and sucrose negative) (Bercovier et al., 1980), the strains appeared to be heterogeneous in their electrophoretic pattern.

The mean genetic diversity coefficient of enzymes (Nei, 1978; Selander et al., 1986) calculated from the electrophoretic data for MDH, GDH, AP and for esterase $\mathrm{E}_{1}$, esterase $\mathrm{E}_{\alpha \mathrm{a}}$ and esterases $\mathrm{E}_{6}$ and $\mathrm{E}_{7}$ increased from $Y$. intermedia $(0.221)$ to $Y$. aldovae $(0.351)$, $Y$. enterocolitica $(0.392)$ and $Y$. frederiksenii (0.494). Good correlation between enzyme polymorphism and DNA heterogeneity for the four species was demonstrated by the existence of a linear relationship between the mean genetic diversity coefficient of the six enzymes and the average percentage DNA-DNA relatedness obtained by Brenner et al. (1980a) and Bercovier et al. (1984) (Fig. 1).

The authors thank Professor H. H. Mollaret for strains and Madame C. Gaillard and Madame N. Hautier for technical assistance. This work was supported by grant from the Conseil Scientifique de la Faculté Xavier Bichat (Université Paris VII). 


\section{REFERENCES}

BAKER, P. M. \& FARMER, J. J., III (1982). New bacteriophage typing system for Yersinia enterocolitica, Yersinia kristensenii, Yersinia frederiksenii and Yersinia intermedia. Correlation with serotyping, biotyping and antibiotic susceptibility. Journal of Clinical Microbiology 15, 491-502.

Baptist, J. N., Shaw, C. R. \& Mandel, M. (1969). Zone electrophoresis of enzymes in bacterial taxonomy. Journal of Bacteriology 99, 180-188.

Bercovier, H. \& Mollaret, H. H. (1984). Yersinia. In Bergey's Manual of Systematic Bacteriology, vol. 1, pp. 498-506. Edited by N. R. Krieg. Baltimore: Williams \& Wilkins.

Bercovier, H., Brault, J., Barre, N., Treignier, M., Alonso, J. M. \& Mollaret, H. H. (1978). Biochemical, serological and phage typing characteristics of 459 Yersinia strains isolated from a terrestrial ecosystem. Current Microbiology 1, 353-357.

Bercovier, H., Ursing, J., Brenner, D. J., Steigerwalt, A. G., Fanning, G. R., Carter, G. P. \& MollaRET, H. H. (1980). Yersinia kristensenii: a new species of Enterobacteriaceae composed of sucrosenegative strains (formerly called atypical Yersinia enterocolitica or Yersinia enterocolitica-like). Current Microbiology 4, 219-224.

Bercovier, H., Steigerwalt, A. G., Guiyoule, A., Huntley-Carter, G. \& Brenner, D. J. (1984). Yersinia aldovae (formerly Yersinia enterocolitica-like group X2): a new species of Enterobacteriaceae isolated from aquatic ecosystems. International Journal of Systematic Bacteriology 34, 166-172.

Brenner, D. J., Ursing, J., Bercovier, H., SteigerWalt, A. G., Fanning, G. R., Alonso, J. M. \& MollaRet, H. H. (1980a). Deoxyribonucleic acid relatedness in Yersinia enterocolitica and Yersinia enterocolitica-like organisms. Current Microbiology 4, 195-200.

Brenner. D. J., Bercovier, H., Ursing, J., Alonso, J. M., Steigerwalt, A. G., Fanning, G. R., Carter, G. P. \& Mollaret, H. H. (1980 b). Yersinia intermedia: a new species of Enterobacteriaceae composed of rhamnose-positive, melibiose positive, raffinose-positive strains (formerly called Yersinia enterocolitica or Yersinia enterocolitica-like). Current Microbiology 4, 207-212.

GoulleT, PH. (1980). Distinctive electrophoretic patterns of esterases from Klebsiella pneumoniae, $K$. oxytoca, Enterobacter aerogenes and $E$. gergoviae. Journal of General Microbiology 117, 483-491.

Goullet, Ph. \& PiCard, B. (1984a). Distinctive electrophoretic and isoelectric focusing patterns of esterases from Yersinia enterocolitica and Yersinia pseudotuberculosis. Journal of General Microbiology 130. $1471-1480$.
Goullet, PH. \& PiCard, B. (1984b). Typage électrophorétique des esterases d'Escherichia coli au cours de septicémies. Presse médicale 13, 1079-1081.

Goullet, Ph. \& Picard, B. (1985a). A two-dimensional electrophoretic profile for bacterial esterases. Electrophoresis 6, 132-135.

Goullet, Ph. \& Picard, B. (1985b). Etude du polymorphisme électrophorétique des lactate-, malate- et glutamate-deshydrogenases, de la phosphatase acide et des esterases de Providencia alcalifaciens, $P$. stuartii et $P$. rustigianii. Annales de l'Institut Pasteur/Microbiologie 136A, 347-358.

Goullet, Ph. \& PICARD, B. (1986). Characterization of Enterobacter cloacae and E. sakazakii by electrophoretic polymorphism of acid phosphatase, esterases, and glutamate, lactate and malate dehydrogenases. Journal of General Microbiology 132, 3105-3112.

LENNOX, E. S. (1955). Transduction of linked characters of the host by bacteriophage PI. Virology 1, 190-206.

NEI, M. (1978). Estimation of average heterozygosity and genetic distance from a small sample of individuals. Genetics 89, 583-590.

Picard, B. \& Goullet, Ph. (1985). Comparative electrophoretic profiles of esterases, and of glutamate, lactate and malate dehydrogenases, from Aeromonas hydrophila, $A$, caviae and $A$. sobria. Journal of General Microbiology 131, 3385-3391.

Picard, B., Krishnamoorthy, R. \& Goullet, Ph. (1987). Enzyme polymorphism in bacteria: study of molecular relatedness by combined isoelectric focusing-electrophoresis. Electrophoresis 8, 149-152.

Selander, R. K., Caugant, D. A., Ochman, H., Musser, J. M., Gilmour, M. N. \& Whittam, T. S. (1986). Methods of multilocus enzyme electrophoresis for bacterial population genetics and systematics. Applied and Environmental Microbiology 51, 873884.

Siciliano, M. \& Shaw, C. R. (1976). Separation and visualization of enzymes on gels. In Chromatographic and Electrophoretic Techniques, 4th edn, vol. 2, pp. 185-209. Edited by I. Smith. Chicago: Yearbook Medical Publishers.

URIEL, J. (1963). Caracterisation d'enzymes par électrophorèse en gélose. In Technique de Laboratoire, pp. 930-935. Edited by J. Loiseleur. Paris: Masson.

URSING, J., BRENNer, D. J., Bercovier, H., FANNING, R., Steigerwalt, A. G., Brault, J. \& Mollaret, H. H. (1980). Yersinia frederiksenii: a new species of Enterobacteriaceae composed of rhamnose-positive strains (formerly called atypical Yersinia enterocolitica or Yersinia enterocolitica-like). Current Microbiology 4, 213-217. 